\title{
Skeletal muscle fatty acid transporter protein expression in type 2 diabetes patients compared with overweight, sedentary men and age-matched, endurance-trained cyclists.
}

Citation for published version (APA):

Pelsers, M. M., Tsintzas, K., Boon, H., Jewell, K., Norton, L., Luiken, J. J. F. P., Glatz, J. F., \& van Loon, L. J. (2007). Skeletal muscle fatty acid transporter protein expression in type 2 diabetes patients compared with overweight, sedentary men and age-matched, endurance-trained cyclists. Acta Physiologica, 190(3), 209-219. https://doi.org/10.1111/j.1748-1716.2007.01698.x

Document status and date:

Published: 01/01/2007

DOI:

10.1111/j.1748-1716.2007.01698.x

Document Version:

Publisher's PDF, also known as Version of record

Document license:

Taverne

Please check the document version of this publication:

- A submitted manuscript is the version of the article upon submission and before peer-review. There can be important differences between the submitted version and the official published version of record. People interested in the research are advised to contact the author for the final version of the publication, or visit the DOI to the publisher's website.

- The final author version and the galley proof are versions of the publication after peer review.

- The final published version features the final layout of the paper including the volume, issue and page numbers.

Link to publication

\footnotetext{
General rights rights.

- You may freely distribute the URL identifying the publication in the public portal. please follow below link for the End User Agreement:

www.umlib.nl/taverne-license

Take down policy

If you believe that this document breaches copyright please contact us at:

repository@maastrichtuniversity.nl

providing details and we will investigate your claim.
}

Copyright and moral rights for the publications made accessible in the public portal are retained by the authors and/or other copyright owners and it is a condition of accessing publications that users recognise and abide by the legal requirements associated with these

- Users may download and print one copy of any publication from the public portal for the purpose of private study or research.

- You may not further distribute the material or use it for any profit-making activity or commercial gain

If the publication is distributed under the terms of Article 25fa of the Dutch Copyright Act, indicated by the "Taverne" license above, 


\title{
Skeletal muscle fatty acid transporter protein expression in type 2 diabetes patients compared with overweight, sedentary men and age-matched, endurance-trained cyclists
}

\author{
M. M. A. L. Pelsers, ${ }^{1}$ K. Tsintzas, ${ }^{2}$ H. Boon, ${ }^{3}$ K. Jewell, ${ }^{2}$ L. Norton, ${ }^{2}$ J. J. F. P. Luiken, ${ }^{4}$ J. F. C. Glatz ${ }^{4}$ \\ and L. J. C. van Loon ${ }^{1,3}$ \\ I Department of Movement Sciences, Maastricht University, Maastricht, the Netherlands \\ 2 Institute of Clinical Research, University of Nottingham Medical School, Nottingham, UK \\ 3 Department of Human Biology, Maastricht University, Maastricht, the Netherlands \\ 4 Department of Molecular Genetics, Maastricht University, Maastricht, the Netherlands
}

Received 3 October 2006, revision requested II December 2006,

revision received 8 January 2006, accepted 24 January 2007 Correspondence: M. Pelsers, PhD, Department of Movement Sciences, Maastricht University, PO Box 616, 6200 MD Maastricht, the Netherlands.

E-mail:

maurice.pelsers@bw.unimaas.nl

\begin{abstract}
Aim: Membrane fatty acid transporters can modulate the balance between fatty acid uptake and subsequent storage and/or oxidation in muscle tissue. As such, skeletal muscle fatty acid transporter protein expression could play an important role in the etiology of insulin resistance and/or type 2 diabetes. Methods: In the present study, fatty acid translocase (FAT/CD36), plasma membrane-bound fatty acid-binding protein (FABPpm) and fatty acid transport protein 1 (FATP1) mRNA and protein expression were assessed in muscle tissue obtained from 10 sedentary, overweight type 2 diabetes patients ( $60 \pm 2$ years), 10 sedentary, weight-matched normoglycemic controls (60 \pm 2 years) and 10 age-matched, endurance trained cyclists ( $57 \pm 1$ years).

Results: Both FAT/CD36 and FATP1 mRNA and protein expression did not differ between groups. In contrast, FABPpm mRNA and protein expression were approx. $30-40 \%$ higher in the trained men compared with the diabetes patients $(P<0.01)$ and sedentary controls $(P<0.05)$.

Conclusions: Skeletal muscle FAT/CD36, FABPpm and FATP1 mRNA and protein expression are not up- or downregulated in a sedentary and/or insulin resistant state. In contrast, FABPpm expression is upregulated in the endurance trained state and likely instrumental to allow greater fatty acid oxidation rates.
\end{abstract}

Keywords CD36, exercise, FABPpm, FATP1, GLUT4, metabolism, muscle.
Numerous studies have reported strong associations between elevated plasma long-chain fatty acid (LCFA) concentrations, increased LCFA uptake, intramyocellular triacyl-glycerol (IMTG) accumulation and the development of insulin resistance and/or type 2 diabetes (Boden 1996, Roden et al. 1996, Pan et al. 1997, Perseghin et al. 1999, Kelley \& Mandarino 2000, Shulmann 2000). However, the relationship between elevated IMTG stores and insulin resistance does not appear to be functional, as endurance trained athletes are markedly insulin-sensitive, despite elevated IMTG levels (Goodpaster et al. 1999, van Loon et al. 2004). The latter is explained by the fact that it is not the actual size or distribution of the IMTG pool but rather the imbalance between increased LCFA availability, uptake and/or decreased oxidation that is responsible for the development of skeletal muscle insulin resistance (Jensen 2002, Kelley 
et al. 2002, van Loon et al. 2004, van Loon \& Goodpaster 2006). In accordance, insights from various lipid infusion studies suggest that elevated LCFA uptake and/or impaired oxidation result in intramyocellular accumulation of LCFA metabolites (such as fatty acyl-CoA, ceramides and diacylglycer$\mathrm{ol}$ ), which are likely to induce defects in the insulin signalling cascade, causing skeletal muscle insulin resistance (Roden et al. 1996, Ellis et al. 2000, Kelley \& Mandarino 2000, Itani et al. 2002, Yu et al. 2002, Adams et al. 2004).

Although LCFA uptake in skeletal muscle tissue can occur through passive diffusion (Hamilton et al. 2001), LCFA are also actively taken up by transporter proteins in the sarcolemma (Bonen et al. 1998a, Abumrad et al. 1999). Intramyocellular LCFA unloading of these transporters is facilitated by cytoplasmic plasma membrane-bound fatty acid-binding protein $\left(\mathrm{FABP}_{\mathrm{c}}\right)$ and acyl-CoA binding protein (ACBP), which also serve as an intracellular LCFA buffer (Glatz et al. 2002). Therefore, LCFA transporter expression could represent an important factor modulating the balance between LCFA uptake and oxidation (Simoneau et al. 1999, Bruce et al. 2003, Bonen et al. 2004, Roepstorff et al. 2004, Koonen et al. 2005, Kiens 2006). Currently, three membrane-bound lipid-binding proteins have been identified that mediate skeletal muscle LCFA uptake (Kiens et al. 1997, Bonen et al. 1999, Roepstorff et al. 2004). Fatty acid translocase (FAT/ CD36, $88 \mathrm{kDa}$ ), is a heavily glycosylated integral membrane protein with two predicted transmembrane domains and has been shown to be of major importance for the uptake of LCFA (Febbraio et al. 1999, Koonen et al. 2005). Plasma membrane-bound fatty acid-binding protein (FABPpm, $43 \mathrm{kDa}$ ) is located peripherally on the plasmamembrane and is identical to mitochondrial aspartate aminotransferase (Stremmel et al. 1985, Stump et al. 1993). The third one is fatty acid transport protein (FATP, $63 \mathrm{kDa}$ ), an integral protein with six predicted transmembrane domains (Schaffer \& Lodisch 1994, Hirsch et al. 1998, Bonen et al. 1999, Pohl et al. 2004). So far six FATP isomers have been identified of which FATP1 is mainly expressed in skeletal muscle tissue (Hirsch et al. 1998).

The role of these transporter proteins in mediating LCFA uptake in muscle tissue is not yet fully understood, but various reports suggest that they are involved in the adaptive response to exercise (Kiens et al. 1997, 2004, Kiens 2006), as well as in the aetiology of insulin resistance and/or type 2 diabetes (Febbraio et al. 1999, Simoneau et al. 1999, Bonen et al. 2004, Kiens 2006). Previous studies have reported an upregulation of mixed muscle FABPpm protein content in obese subjects (Simoneau et al. 1999) and type 2 diabetes patients (Bruce et al. 2003). However, others have been unable to confirm these findings (Bonen et al. 2004). Furthermore, studies investigating the effects of training status on skeletal muscle LCFA transporter mRNA or protein expression have also reported contradictory findings (Tunstall et al. 2002, Kiens et al. 2004, Kiens 2006). Skeletal muscle sarcolemmal FAT/CD36 content is rapidly upregulated in response to acute exercise, whereas more long-term endurance training is needed to upregulate sarcolemmal FABPpm content (Tunstall et al. 2002, Kiens et al. 2004, Kiens 2006).

Because LCFA uptake is elevated in type 2 diabetes (Luiken et al. 2001, Bonen et al. 2004), we aimed to assess whether skeletal muscle mRNA and/or protein expression of the different LCFA transporter proteins are upregulated in type 2 diabetes patients. As it has recently been stressed that physically active subjects should act as controls when evaluating the effects of chronic metabolic disease on substrate use (Booth \& Lees 2006), we assessed FAT/CD36, FABPm and FATP mRNA and protein expression in muscle tissue collected from both matched, sedentary controls as well as healthy, active men. As such, we provide a complete overview on skeletal muscle mRNA and protein expression of each of the LCFA transporter proteins in three well matched groups of subjects: 10 type 2 diabetes patients (60 \pm 2 years), 10 matched sedentary, normoglycemic controls ( $60 \pm 2$ years), and 10 age-matched, endurance trained men (57 \pm 1 years).

\section{Methods}

\section{Subjects}

A total of 10 sedentary, overweight type 2 diabetes patients (male, $60 \pm 2$ years), 10 sedentary, weightmatched, normoglycemic controls (male, $60 \pm 2$ years), and 10 age-matched endurance trained cyclists (male, $57 \pm 1$ years, minimum of 25 years cycling experience) were selected to participate in this study (Table 1). Type 2 diabetes patients and sedentary controls had not been engaged in any regular exercise programme. In contrast, the trained subjects exercised between three and four times a week, cycling at least $200 \mathrm{~km} \mathrm{week}^{-1}$. Type 2 diabetes patients and sedentary controls were matched for age, bodyweight and maximal oxygen uptake capacity. All type 2 diabetes patients were using oral blood glucose lowering medication (metformin with or without sulphonylurea derivatives). Type 2 diabetes status was verified with an oral glucose tolerance test (OGTT) according to WHO criteria (Alberti \& Zimmet 1998). The study was approved by the local Medical Ethical Committee. 
Table I Subjects' characteristics

\begin{tabular}{|c|c|c|c|}
\hline & Type 2 diabetes, $n=10$ & Sedentary controls, $n=10$ & Trained controls, $n=10$ \\
\hline Age (years) & $58.9 \pm 2.5$ & $60.0 \pm 1.9$ & $57.4 \pm 0.8$ \\
\hline Height (m) & $1.79 \pm 0.02$ & $1.76 \pm 0.01$ & $1.75 \pm 0.01$ \\
\hline Body mass $(\mathrm{kg})$ & 93. \pm 4.4 & $86.9 \pm 1.9$ & $77.7 \pm 1.8^{\dagger}$ \\
\hline BMI $\left(\mathrm{kg} \mathrm{m}^{-2}\right)$ & $28.9 \pm 1.2$ & $27.5 \pm 0.5$ & $25.5 \pm 0.7^{\dagger}$ \\
\hline Body fat $(\%)$ & $30.4 \pm 1.8$ & $28.9 \pm 1.4$ & $17.2 \pm 11.2 * \dagger$ \\
\hline Fat free mass $(\mathrm{kg})$ & $64.5 \pm 2.4$ & $61.7 \pm 1.6$ & $64.2 \pm 11.2$ \\
\hline Basal plasma LCFA $\left(\mu \mathrm{M} \mathrm{L}^{-1}\right)$ & $626 \pm 56$ & $440 \pm 34^{\dagger}$ & $519 \pm 56$ \\
\hline Basal plasma glucose $(\mathrm{mm})$ & $8.95 \pm 0.43$ & $5.54 \pm 0.16^{\dagger}$ & $5.65 \pm 0.08^{\dagger}$ \\
\hline Plasma glucose ${ }_{120 \min }(\mathrm{mM})$ & $16.81 \pm 1.0$ & $5.34 \pm 0.49^{\dagger}$ & $5.28 \pm 0.4^{\dagger}$ \\
\hline Basal plasma insulin $\left(\mathrm{mU} \mathrm{L}^{-1}\right)$ & $8.70 \pm 1.01$ & $7.86 \pm 1.58$ & $5.13 \pm 0.56$ \\
\hline Plasma insulin $120 \mathrm{~min}$ & $47.24 \pm 9.61$ & $48.40 \pm 8.04$ & $29.40 \pm 6.34$ \\
\hline HbA1c (\%) & $7.30 \pm 0.3$ & $5.83 \pm 0.2^{\dagger}$ & $5.78 \pm 0.1^{\dagger}$ \\
\hline$V \mathrm{O}_{2 \max }\left(\mathrm{L} \mathrm{min}^{-1}\right)$ & $2.9 \pm 0.2$ & $3.2 \pm 0.2$ & $3.8 \pm 0.1 * \dagger$ \\
\hline$V \mathrm{O}_{2 \max }\left(\mathrm{mL} \min ^{-1} \mathrm{~kg}^{-1}\right)$ & $32 \pm 2$ & $37 \pm 2$ & $49 \pm 2 * \dagger$ \\
\hline 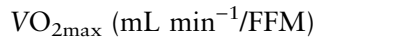 & $45 \pm 2$ & $52 \pm 3$ & $59 \pm 2 * \dagger$ \\
\hline$W_{\max }(\mathrm{W})$ & $205 \pm 16$ & $206 \pm 18$ & $300 \pm 9 * \dagger$ \\
\hline$W_{\max }\left(\mathrm{W} \mathrm{kg}^{-1}\right)$ & $2.20 \pm 0.12$ & $2.33 \pm 0.17$ & $3.87 \pm 0.4^{* \dagger}$ \\
\hline$W_{\max }(\mathrm{W} / \mathrm{FFM})$ & $3.10 \pm 0.16$ & $3.27 \pm 0.20$ & $4.67 \pm 0.13^{* \dagger}$ \\
\hline Maximal heartrate (bpm) & $161 \pm 4$ & $164 \pm 7$ & $172 \pm 3$ \\
\hline Diagnosed with diabetes (years) & $7 \pm 1$ & - & - \\
\hline
\end{tabular}

Data are given as means \pm SEM.

Body mass index (BMI) is calculated dividing body mass by height ${ }^{2}$; Plasma glucose/insulin ${ }_{120 \text { min }}$ represents plasma glucose/insulin concentrations at $t=120 \mathrm{~min}$.

*Significantly different from sedentary control group $(P<0.05)$; ${ }^{\dagger}$ significantly different from type 2 diabetes group $(P<0.05)$.

\section{Screening}

All subjects performed an OGTT. After an overnight fast, subjects arrived at the laboratory at 8 a.m. by car or public transportation. After $30 \mathrm{~min}$ of supine rest, a catheter (Baxter BV, Utrecht, the Netherlands) was inserted into an antecubital vein and a resting blood sample was drawn after which $75 \mathrm{~g}$ glucose (dissolved in $250 \mathrm{~mL}$ water) was ingested. Thereafter, blood samples were collected at $t=120 \mathrm{~min}$ without the use of a cuff. Plasma glucose concentrations (Table 1 ) were measured to assess glucose intolerance and/or type 2 diabetes according to the ADA guidelines of 2003 (Report of the Expert Committee 2003). Maximal power output $\left(W_{\max }\right)$ and maximal oxygen uptake capacity $\left(V \mathrm{O}_{2 \max }\right)$ were determined on an electronically braked cycle ergometer (Lode Excalibur, Groningen, the Netherlands) during an incremental exhaustive exercise test 2 weeks before muscle biopsy collection (Table 1). Oxygen uptake $\left(V_{2}\right)$ and carbondioxide production $\left(\mathrm{VCO}_{2}\right)$ were measured continuously (Oxycon ${ }^{\circledR}$; Mijnhart, Breda, the Netherlands). Body composition was assessed using the hydrostatic weighing method in the morning after an overnight fast. Simultaneously, residual lung volume was measured by the helium-dilution technique using a spirometer (Volugraph 2000; Mijnhart, Bunnik, the Netherlands). Body weight was measured with a digital balance with an accuracy of $1 \mathrm{~g}$ (E1200; August Sauter GmbH, Albstadt, Germany). Body fat percentage was calculated using Siri's equation (Siri 1956). Fat free mass (FFM) was calculated by subtracting fat mass (FM) from total body weight (Table 1).

\section{Diet and physical activity prior to muscle biopsy collection}

All subjects were instructed to refrain from strenuous physical activity for 2 days before biopsy collection, and recorded dietary intake for 2 days. The evening before muscle biopsy collection, all subjects received the same standardized meal $\left[4.2 \mathrm{~kJ} \mathrm{~kg}^{-1}\right.$; consisting of 61 Energy\% (En\%) carbohydrate, $24 \mathrm{En} \%$ fat and $15 \mathrm{En} \%$ protein]. There were no differences in daily energy intake between groups during the days before the tests $\left(8.5 \pm 0.6,9.1 \pm 2.0\right.$ and $9.3 \pm 0.8 \mathrm{MJ} \mathrm{day}^{-1}$ in the type 2 diabetes patients, sedentary- and trained-control group, respectively). Macronutrient composition of the diet consisted of $54.9 \mathrm{En} \%$ carbohydrate, $28.8 \mathrm{En} \%$ fat and $16.3 \mathrm{En} \%$ protein in the type 2 diabetes patients, $52.8 \mathrm{En} \%$ carbohydrate, $31.9 \mathrm{En} \%$ fat and $15.3 \mathrm{En} \%$ protein in the sedentary controls and $52.4 \mathrm{En} \%$ carbohydrate, $29.2 \mathrm{En} \%$ fat and $18.4 \mathrm{En} \%$ protein in the trained controls. The protein intake was significantly higher in the trained controls $(19 \pm 1$ vs. $16 \pm 0$ 
En\%) compared with the diabetes patients and sedentary controls $(P<0.05)$.

\section{Research protocol}

Following an overnight fast, subjects arrived at the laboratory in the morning by car or public transportation. Height was determined and body mass was measured with a digital balance with an accuracy of $0.001 \mathrm{~kg}$ (E1200). Thereafter, a fasting blood sample was collected from an antecubital vein. After $30 \mathrm{~min}$ of supine rest, an anesthetic ( $1 \%$ xylocaine) was injected locally in skin, soft tissue below, and in the muscle fascia in the middle region of the vastus lateralis muscle. Thereafter, a small incision $(5 \mathrm{~mm})$ was made through the skin and the fascia at approx. $15 \mathrm{~cm}$ above the patella. An adapted Bergström needle was inserted to a depth of approx. 2-3 cm below the entry of the fascia and a muscle sample (appro. $60 \mathrm{mg}$ ) was obtained by suction. Muscle tissue was freed from any visible nonmuscle material. Thereafter, one portion was immediately frozen in liquid nitrogen; another portion was frozen immediately in nitrogen-cooled isopentane and embedded in Tissue-Tek (Sakura, Zoeterwoude, the Netherlands). Both samples were stored at $-80{ }^{\circ} \mathrm{C}$ until further analyses.

\section{Protein extraction}

For protein extraction and quantification, muscle samples $(20-30 \mathrm{mg})$ were homogenized $(1.5-10 \% \mathrm{w} / \mathrm{v})$ in Hepes-buffer (50 mm Hepes, $1 \mathrm{~mm}$ EDTA, 10\% glycerol, $10 \mathrm{~mm} \mathrm{NaF}, 1 \mathrm{~mm}$ activated $\mathrm{Na}_{3} \mathrm{VO}_{4}, 150 \mathrm{~mm}$ NaCL, $1 \%$ Triton X-100, pH 7.5) using an UltraTurrax homogenizer $(2 \times 15 \mathrm{~s}$; IKA Werke, Breisgau, Germany). After $20 \mathrm{~min}$ incubation on ice and subsequent centrifugation for $20 \mathrm{~min}$ at $4{ }^{\circ} \mathrm{C}(10000 \mathrm{~g}$, Eppendorf), supernatant was used for total protein quantification with the Pierce micro-BCA assay (23235; Pierce, Rockford, IL, USA) applying bovine serum albumin as standard.

\section{Western blot analyses}

For immunoblot analyses, either $10 \mu \mathrm{g}$ (FAT/CD36 and FABPpm) or $50 \mu \mathrm{g}$ (FATP1) protein of the membraneextract was loaded on a $10 \%$ SDS-PAGE gel (Biorad, Hercules, CA, USA) and run for $50 \mathrm{~min}$ at $200 \mathrm{~V}$. After blotting on nitrocellulose membrane for $90 \mathrm{~min}$ at $100 \mathrm{~V}$, membranes were blocked for $1 \mathrm{~h}$ at room temperature with either bovine serum albumin (Sigma A4503, St. Louis, MO, USA) for FAT/CD36 or non-fat dry milk (NFDM) for FABPpm and FATP1. After washing with TBS-Tween, membranes were incubated $\mathrm{o} / \mathrm{n}$ at $4{ }^{\circ} \mathrm{C}$ with primary antibodies for FAT/CD36
(MO25, 1/20 000 in TBS-tween, provided by N.N. Tandon) and FABPpm (1/3000 in NFDM, provided by J. Calles-Escandon), as previously described (Bonen et al. 1998b) and for FATP1 (Santa Cruz Biotechnology, Santa Cruz, CA, USA; 1/4000 in NFDM). After washing with TBS-Tween, secondary complexes were generated using anti-mouse IgG horseradisch-peroxidase conjugated antibody (1/20 000; Dako Cytomation, Glostrup, Denmark) for FAT/CD36 and anti-rabbit horseradisch-peroxidase conjugated antibody for FABPpm (1/3000; Chemicon, Temecula, CA, USA) and FATP1 (1/3000; Santa Cruz Biotechnology). Enhanced chemiluminescense detection (ECL) was performed with band densities obtained by densitometry. A control sample was run on each gel as loading control. ECL data of this sample was set as $100 \%$ and compared with all other samples.

\section{Immunohistochemistry}

For qualitative immunohistochemical staining, multiple serial sections $(5 \mu \mathrm{m})$ from tissue-tek embedded samples were thaw mounted together on uncoated, pre-cleaned glass slides. To visualize FAT/CD36, FABPpm and FATP1, tissue slides were first stained overnight at $4{ }^{\circ} \mathrm{C}$ with primairy antibodies to FAT/CD36 and FATP1 (Santa Cruz Biotechnology) and to FABPpm. After washing with TBS/Tween, secondary antibodies labelled with either IgA-FITC (FAT/CD36) or IgG-FITC (FABPpm and FATP1) were added for $30 \mathrm{~min}$ incubation followed by three washing steps with TBS before analysis. CD31 antibody was added to allow membrane localization.

\section{Real-time RT-PCR}

For quantitative real-time PCR, total RNA was extracted from 10 to $20 \mathrm{mg}$ of muscle tissue using Trizol reagent (Invitrogen, Breda, the Netherlands). Total RNA quantification was performed with the Ribo-green assay (Molecular Probes, Breda, the Netherlands). The first-strand cDNA was synthesized from $500 \mathrm{ng}$ of total RNA using random primers (Promega, Madison, WI, USA) and Moloney Murine Leukemia Virus Reverse Transciptase (M-MLV RT) (Promega). Samples were subjected to quantitative real-time PCR using TaqMan probes (Sigma) and primer sets (synthesized by J. Keyte, University of Nottingham) for FAT/CD36, FABPpm and FATP1. The ABI PRISM 7000 system was used for the reaction and detection (Applied Biosystems). The probes were labelled with FAM at the $5^{\prime}$ end and with TAMRA at the $3^{\prime}$ end. PCR amplification was performed in a total volume of $25 \mu \mathrm{L}$ containing $5 \mu \mathrm{L}$ of diluted (one in four) cDNA sample, $300 \mathrm{~nm}$ of each primer, $200 \mathrm{~nm}$ of Taqman probe, and $12.5 \mu \mathrm{L}$ of 
Table 2 Sequences for primers and Taqman probes used for real-time PCR

\begin{tabular}{llll}
\hline Gene & Forward primer & Probe & Reverse primer \\
\hline FAT/CD36CTGGAGTCTGGAATTCAGAACGTCCTGCAGGTTCAGTGCCCCC & GAAGTGAGGATGGGAGAGAAACA \\
FABPpm & CACATCACCGACCAAATTGG & ATGTTCTGTTTCACAGGGCTAAAGCAGCCGCTCCACCTGTTCA \\
FATP1 & CGTCCTCCGCAAGAAATTCTC & CAGCCGCTTCTGGGACGACTGC & CTGAACCACCGTGCAGTTGT \\
\hline
\end{tabular}

TaqMan Universal PCR Master Mix. For each reaction, the polymerase was activated by pre-incubation at $95^{\circ} \mathrm{C}$ for $10 \mathrm{~min}$. Amplification was then performed by 40 cycles of $95^{\circ} \mathrm{C}$ for $15 \mathrm{~s}$ and $60{ }^{\circ} \mathrm{C}$ for $60 \mathrm{~s}$. The FAT/CD36, FABPpm and FATP1 cDNA quantity in each sample was normalized to the housekeeping gene hydroxymethylbilane synthase (HMBS) mRNA. The probe and primers for HMBS were obtained from PE Applied Biosystems (Pre-developed TaqMan Assay Reagents Control kits) (Table 2). All other probes and primer sets (Table 2) were designed by K. Jewell (University of Nottingham). Real-time PCR was carried out in triplicate for each sample.

\section{Statistics}

All data are expressed as means \pm SEM. To compare energy expenditure, food intake, fatty acid transporter mRNA and protein expression between groups, a onefactor analysis of variance (ANOVA) was applied. A Scheffé's post hoc test was applied in case of a significant F-ratio to locate specific differences. Significance was set at the 0.05 level of confidence.

\section{Results}

\section{Subjects' characteristics}

Fasting blood glucose and LCFA concentrations as well as $\mathrm{HbA} 1 \mathrm{c}$ content were significantly higher in the type 2 diabetes patients when compared with the sedentary and/or trained control groups (Table 1). Type 2 diabetes patients and sedentary controls were matched for age, maximal power output $\left(W_{\max }\right)$, maximal oxygen uptake and body composition. The endurance trained group showed a significantly greater maximal power output $\left(W_{\max }\right)$ and maximal oxygen uptake capacity, expressed either per $\mathrm{kg}$ lean body mass (LBM) or per $\mathrm{kg}$ bodyweight $(\mathrm{BW})$, when compared with the sedentary controls and type 2 diabetes patients $(P<0.05)$.

\section{FAT/CD36}

Total skeletal muscle FAT/CD36 protein content did not differ between groups (Fig. 1a). FAT/CD36 mRNA expression did not show any significant differences

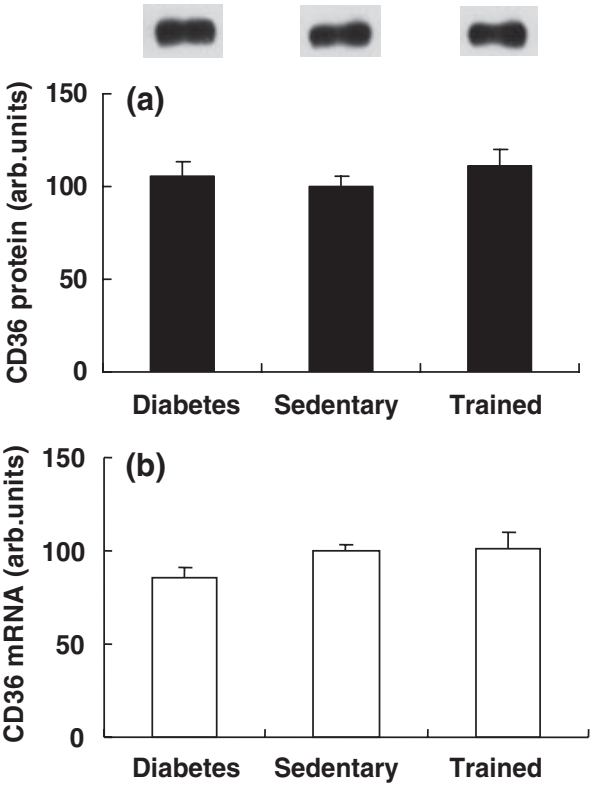

Figure I Mixed muscle total protein (a) and mRNA, (b) content of FAT/CD36 measured in type 2 diabetes patients, age- and BMI matched sedentary controls and endurance trained active controls. Representable Western blot is shown (a). Data for each gene were normalized to HMBS and expressed as mean \pm SEM. No significantly differences between groups.

between type 2 diabetes patients and sedentary and/or endurance trained controls (Fig. 1b). Immunohistochemical staining showed FAT/CD36 expressed both in endothelial cells and the sarcolemma (Fig. 4a).

\section{FABPpm}

Total skeletal muscle FABPpm protein content was significantly higher $(30 \%)$ in the endurance trained group when compared with the sedentary controls and type 2 diabetes patients $(P<0.01$; Fig. $2 a)$. In accordance, FABPpm mRNA expression was significantly higher $(28-37 \%)$ in the endurance trained group compared with the sedentary controls and type 2 diabetes patients $(P<0.05$; Fig. $2 \mathrm{~b})$. Immunohistochemical staining showed FABPpm expressed in endothelial cells and in the sarcolemma (Fig. 4b, green dots). Orange dots indicate CD31 staining on endothelial cells. 

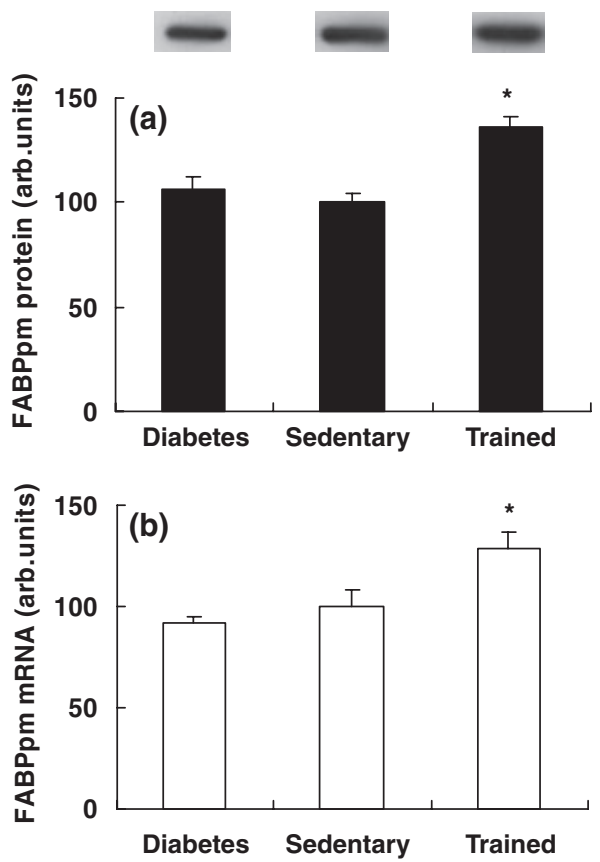

Figure 2 Mixed muscle total protein (a) and mRNA (b) content of FABPpm measured in type 2 diabetes patients, matched sedentary and endurance trained controls. Representable Western blot is shown (a). Data for each gene were normalized to hydroxymethylbilane synthase (HMBS) and expressed as mean \pm SEM. "Significantly higher than in diabetes patients and sedentary controls $P<0.01$.

\section{FATPI}

Total skeletal muscle FATP1 mRNA and protein content did not differ between groups (Fig. 3a, b). Immunohistochemical staining showed FATP1 located in the sarcolemma and endothelial cells (Fig. 4c).

No significant correlations between muscle transporter contents were observed, (FAT/CD36-FABPpm: $\left.R^{2}=0.2433\right),\left(\right.$ FAT/CD36-FATP1: $\left.R^{2}=0.1501\right)$ and (FATP1-FABPpm: $R^{2}=0.0389$ ).

\section{Discussion}

In obesity and/or type 2 diabetes, a structural imbalance between LCFA availability, uptake, storage and/or oxidation is responsible for the development of skeletal muscle insulin resistance (Roden et al. 1996, Pan et al. 1997, Bonen et al. 1998a, Goodpaster et al. 1999, Perseghin et al. 1999, Kelley \& Mandarino 2000, Shulmann 2000, Kelley et al. 2002, van Loon et al. 2004, van Loon \& Goodpaster 2006). Elevated LCFA uptake and/or impaired LCFA oxidation lead to intramyocellular accumulation of FA metabolites (such as fatty acyl-CoA, ceramides and diacylglycerol), which can induce defects in the insulin signaling cascade,

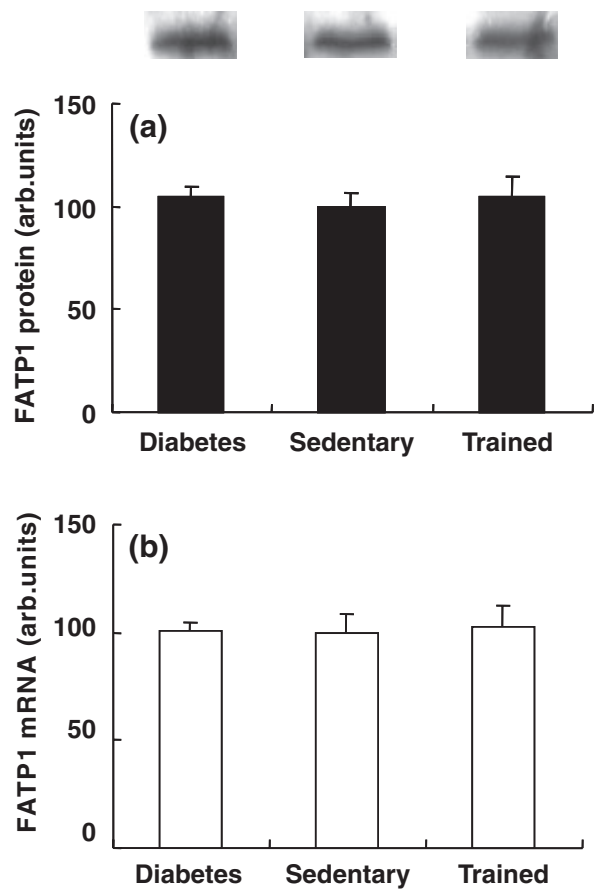

Figure 3 Mixed muscle total protein (a) and mRNA (b) content of FATP1 in type 2 diabetes patients, matched sedentary and endurance trained controls. Representable Western blot is shown (a). Data for each gene were normalized to hydroxymethylbilane synthase (HMBS) and expressed as mean \pm SEM. No significant differences between groups.

causing skeletal muscle insulin resistance (Roden et al. 1996, Ellis et al. 2000, Kelley \& Mandarino 2000, Itani et al. 2002, Yu et al. 2002, Adams et al. 2004). Skeletal muscle LCFA transporters play an important role in modulating the balance between plasma LCFA availability and subsequent LCFA storage and/or oxidation by mediating LCFA uptake (Luiken et al. 2001, Bonen et al. 2002). As such, skeletal muscle LCFA transporter content could represent an important factor in the development and/or progression of skeletal muscle insulin resistance. The present study compares mRNA and protein expression of the LCFA transporter proteins in muscle tissue obtained from overweight, type 2 diabetes patients, matched sedentary controls, and agematched, endurance-trained cyclists. No differences in muscle FAT/CD36, FABPpm and FATP1 mRNA and protein expression were observed between type 2 diabetes patients and matched, sedentary controls. As such, we show that FAT/CD36, FABPpm and FATP1 are not expressed differently in the type 2 diabetes state when subjects are matched for maximal oxygen uptake capacity. Bruce et al. (2003) reported comparable results for FAT/CD36 but showed a lower FABPpm content in matched elderly controls vs. diabetes 

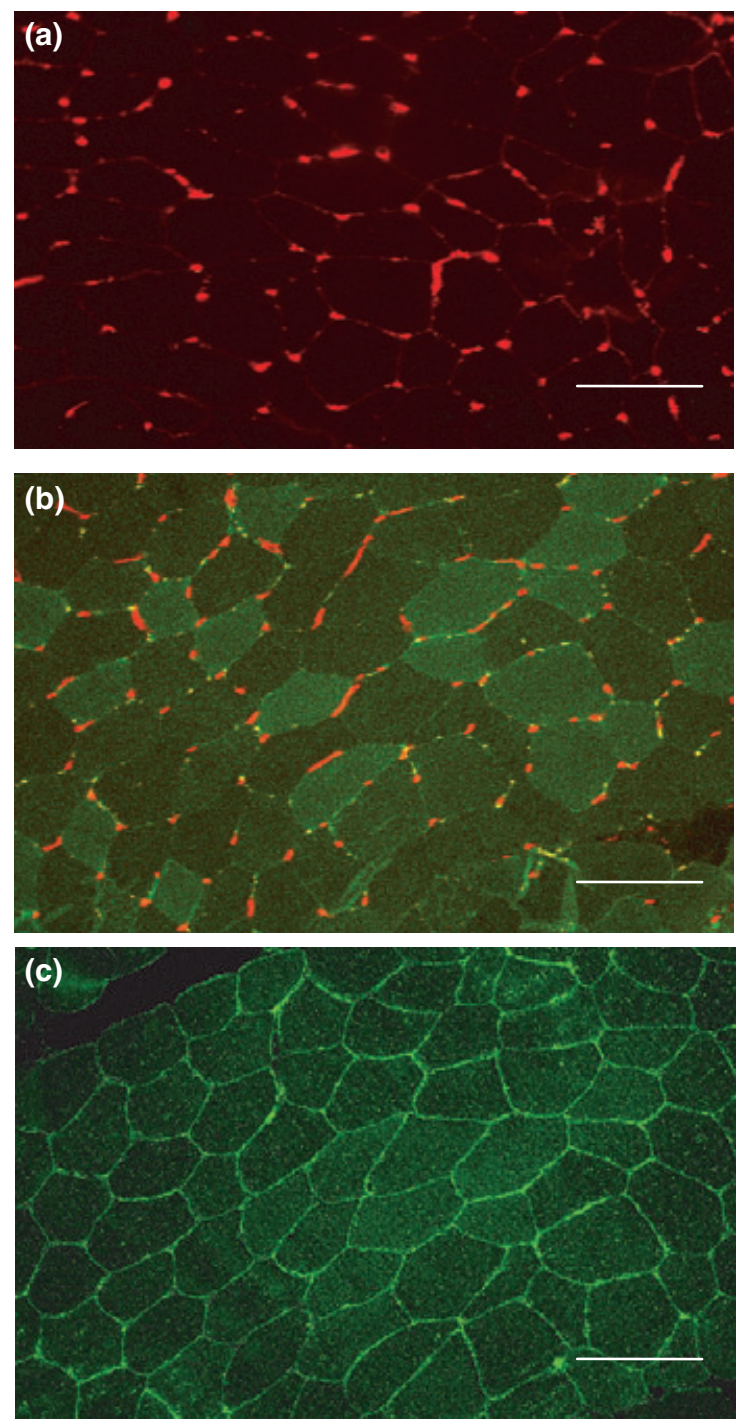

Figure 4 Immunohistochemical staining of CD36 (a), FABPpm (b), and FATP1 (c) in a muscle cross-section. Horizontal bar represents $100 \mu \mathrm{m}$.

patients. Furthermore, in contrast to FAT/CD36 and FATP1, we show that in FABPpm mRNA and protein expression are upregulated in the endurance trained vs. sedentary men. The latter is in line with observations in young males (Kiens et al. 1997, 2004).

\section{FAT/CD36}

Rodent studies have shown that skeletal muscle FAT/ CD36, located in the plasma membrane, forms an important mediating role in skeletal muscle LCFA uptake (Febbraio et al. 1999, Ibrahimi et al. 1999). Recently, it was reported that FAT/CD36 is also located in the mitochondrial membrane (Campbell et al. 2004, Bezaire et al. 2006, Holloway et al. 2006). However, the latter is difficult to verify by immunohistochemical staining, as intracellular FAT/CD36 staining is minimal (Keizer et al. 2004, Vistisen et al. 2004). FAT/CD36 knock-out mice show a substantial decline in skeletal muscle LCFA uptake (Febbraio et al. 1999), whereas overexpression of FAT/CD36 has been shown to enhance LCFA oxidation rates in contracting rodent muscle (Ibrahimi et al. 1999). More recent human studies report greater FAT/CD36 protein content in vastus lateralis muscle in women compared with men (Kiens et al. 2004). The latter could be attributed to the fact that women have a higher type 1 muscle fibre content than men (Steffensen et al. 2002, Vistisen et al. 2004), as FAT/CD36 is expressed to a greater extent in type 1 muscle fibres (Keizer et al. 2004, Vistisen et al. 2004). Furthermore, basal LCFA flux is significantly higher in women compared with men (Koutsari \& Jensen 2006), which could also be responsible for greater muscle FAT/ CD36 expression in women. In accordance, elevated plasma LCFA concentrations after a high fat diet have been shown to upregulate skeletal muscle FAT/CD36 mRNA (Cameron-Smith et al. 2003) and protein (Roepstorff et al. 2004) expression. As insulin resistance and/or type 2 diabetes are generally accompanied by elevated plasma LCFA availability (Roden et al. 1996, Pan et al. 1997, Bonen et al. 1998a, Perseghin et al. 1999, Kelley \& Mandarino 2000, Shulmann 2000), it seems reasonable to speculate that FAT/CD36 protein expression might also be upregulated in the type 2 diabetes state. However, we did not observe any differences in total muscle FAT/CD36 mRNA or protein content between type 2 diabetes patients and matched sedentary controls, which is in accordance with previous studies (Bruce et al. 2003, Bonen et al. 2004). We extend on these previous findings by the assessment of FAT/ CD36 protein expression in muscle tissue taken from age-matched, endurance-trained controls. But even in these active males, no differences in FAT/CD36 mRNA or protein expression were evident (Fig. 1). The latter is in line with previous cross-sectional studies (Bruce et al. 2003, Kiens et al. 2004). However, it should be noted that studies investigating more acute or short-term responses to exercise have reported either an increase in FAT/CD36 mRNA expression after $90 \mathrm{~min}$ of exercise (Kiens et al. 2004) or an increase in FAT/CD36 mRNA and protein content after 8 days of training (Tunstall et al. 2002). FAT/CD36 therefore likely forms a more temporary adaptive response to allow greater fat utilization, but does not seem to result in a structural increase in skeletal muscle FAT/CD36 protein content (Kiens et al. 2004).

\section{FABPpm}

FABPpm has been suggested to be co-localized with FAT/ CD36 on the sarcolemma and functions as an important LCFA transport protein (Bonen et al. 2002). In rat 
muscle, fasting has been shown to upregulate sarcolemmal FABPpm protein expression (Turcotte et al. 1997). Human studies have reported greater FABPpm protein content in vastus lateralis muscle in obese men and women (Simoneau et al. 1999), type 2 diabetes patients (Bruce et al. 2003) or long-term high fat fed subjects (Roepstorff et al. 2004) vs. sedentary controls. In the present study, we show no differences in muscle FABPpm protein content between overweight, type 2 diabetes patients and matched sedentary controls. However, Bruce et al. (2003) showed significant lower FABPpm expression in weight-matched elderly controls vs. type 2 diabetes patients and young controls. In the present study, we show a significant upregulation of FABPpm mRNA and protein expression in the endurance trained males. The latter tends to be in line with previous work (Kiens et al. 1997, Tunstall et al. 2002) and implies that FABPpm content is an important factor in allowing greater LCFA oxidation in the endurance trained state.

\section{FATPI}

Although initially FATP1 was merely thought to function as very-long chain fatty acyl-CoA synthase (Coe et al. 1999), Wu et al. (2006) recently reported that FATP1 also acts as an insulin-sensitive LCFA transporter involved in diet-induced obesity in rodents. Skeletal muscle of FATP1-null mice showed reduced insulinstimulated LCFA uptake (Wu et al. 2006). Therefore, we also assessed FATP1 mRNA and protein expression in skeletal muscle tissue in type 2 diabetes patients, sedentary controls and age-matched, endurance trained men. We did not detect any differences in muscle FATP1 expression between groups. Though data on FATP1 protein expression in human muscle are scarce, FATP1 mRNA (Binnert et al. 2000, Kiens et al. 2004) or protein (Bandyopadhyay et al. 2006) expression have been reported to be uninfluenced by training status (Kiens et al. 2004) and/or the obese and/or type 2 diabetes state (Binnert et al. 2000, Bandyopadhyay et al. 2006). However, it should be noted that the latter has been speculated to be gender specific (Binnert et al. 2000). In accordance with Bandyopadhyay et al. (2006), we show that total muscle FATP1 content is not upregulated or downregulated in the type 2 diabetes and/or sedentary state. Because it is not known whether sarcolemmal FATP1 content or enzymatic activity varies in the type 2 diabetes state, it remains speculative whether FATP1 plays a major role in the aetiology of insulin resistance and/or type 2 diabetes.

\section{Overall conclusions and perspectives}

Although modulating LCFA transporter content through pharmaceutical intervention could represent an effective approach to reduce plasma FA uptake, our data indicate that variations in total LCFA transporter content do not seem responsible for metabolic impairments observed in chronic metabolic disease. Skeletal muscle FAT/CD36, FABPpm and FATP1 protein expression do not seem to be dysregulated in the type 2 diabetes and/or sedentary state. However, for a transporter to be functional it needs to be located at the sarcolemma. Interestingly all the transporters have been reported to be present both at the sarcolemma as well as in various intracellular (endosomal and mitochondrial) compartments, where they are stored (Binnert et al. 2000, Bonen et al. 2000, Campbell et al. 2004, Chabowski et al. 2005). Moreover, the three LCFA transporters have been shown to translocate from the endosomal pools to the sarcolemma to upregulate LCFA uptake in a manner similar to the translocation of GLUT4 upregulating glucose transport (Douen et al. 1990, Hirshman et al. 1990, Kennedy et al. 1999). In isolated cardiac myocytes (Luiken et al. 2003, Chabowski et al. 2005), perfused rat hindlimb muscle (Luiken et al. 2002) as well as in giant vesicles prepared from skeletal muscle (Bonen et al. 2000), both insulin and muscle contraction have been reported to stimulate FAT/ CD36 translocation to the membrane. FABPpm translocation has been reported to be induced by muscle contraction only (Chabowski et al. 2005), whereas FATP1 shows an insulin induced translocation from intracellular pools to the plasma membrane in both adipocytes (Stahl et al. 2002) and skeletal muscle (Wu et al. 2006). In type 2 diabetic rat and human skeletal muscle and heart, FAT/CD36 has been reported to be permanently relocated to the sarcolemma at the expense of intracellular stores and in the absence of changes in total expression (Bonen et al. 2004, Koonen et al. 2005). As we did not observe any apparent differences in LCFA transporter mRNA and/or protein expression in skeletal muscle tissue in the sedentary and/ or type 2 diabetes state, we need to address possible impairments in LCFA transporter translocation next. Until recently (Bandyopadhyay et al. 2006), the amount of muscle tissue needed to quantify the amount of LCFA transporter in the sarcolemma has limited the progress on the assessment of the LCFA transporter translocation.

We conclude that total skeletal muscle FAT/CD36, FABPpm and FATP1 mRNA and protein expression are not upregulated or downregulated in a sedentary and/or type 2 diabetes state, and as such, are not responsible for the impairments in fat metabolism associated with type 2 diabetes. FABPpm expression is upregulated in the endurance trained state and is likely instrumental to allow greater fatty acid oxidation rates.

\section{Conflict of interest}

There is no conflict of interest. 
We thank Dr Tandon (Otsuka Research Maryland, Bethesda, MD, USA) and Dr Calles-Escandon (SmithKlineBeecham, Miama, FL, USA) for providing the antibodies for FAT/ CD36 and FABPpm, respectively. We gratefully acknowledge the enthusiastic support from the volunteers participating in this experiment and Richard Jonkers for technical assistance. This study was supported by the Netherlands Heart Foundation (grant 2002.T049) and the European Commission (Integrated Project LSHM-CT-2004-005272, Exgenesis). Joost Luiken is the recipient of a VIDI-Innovational Research Grant from the Netherlands Organization of Scientific Research (NWO-ZonMw grant 016.036.305). Jan Glatz is Netherlands Heart Foundation Professor or Cardiac Metabolism.

\section{References}

Abumrad, N., Coburn, C. \& Ibrahimi, A. 1999. Membrane proteins implicated in long-chain fatty acid uptake by mammalian cells: CD36, FATP and FABPpm. Biochim Biophys Acta 1441, 4-13.

Adams, J., Pratipanawatr, T., Berria, R. et al. 2004. Ceramide content is increased in skeletal muscle from obese insulin resistant humans. Diabetes 53, 25-31.

Alberti, K. \& Zimmet, P. 1998. Definition, diagnosis and classification of diabetes mellitus and its complications. Part 1: diagnosis and classification of diabetes mellitus provisional report of a WHO consultation. Diabet Med 15, 539553.

Bandyopadhyay, G., Yu, J., Ofrecio, J. \& Olefsky, J. 2006. Increased malonyl-CoA levels in muscle from obese and type 2 diabetic subjects lead to decreased fatty acid oxidation and increased lipogenesis; thiazolidinedione treatment reverses these defects. Diabetes 55, 2277-2285.

Bezaire, V., Bruce, C., Heigenhauser, G. et al. 2006. Identification of fatty acid translocase on human skeletal muscle mitochondrial membranes: essential role in fatty acid oxidation. Am J Physiol Endocrinol Metab 290, E509-E515.

Binnert, C., Koistinen, H., Martin, G. et al. 2000. Fatty acid transport protein-1 mRNA expression in skeletal muscle and in adipose tissue in humans. Am J Physiol Endocrinol Metab 279, E1072-E1079.

Boden, G. 1996. Role of fatty acids in the pathogenesis of insulin resistance and NIDDM. Diabetes 45, 3-10.

Bonen, A., Dyck, D. \& Luiken, J. 1998a. Skeletal muscle fatty acid transport and transporters. Adv Exp Med Biol 441, 193-205.

Bonen, A., Luiken, J., Liu, S. et al. 1998b. Palmitate transport and fatty acid transporters in red and white muscles. Am J Physiol Endocrinol Metab 275, E471-E478.

Bonen, A., Miskovic, D. \& Kiens, B. 1999. Fatty acid transporters (FABPpm, FAT, FATP) in human muscle. Can J Appl Physiol 24, 515-523.

Bonen, A., Luiken, J., Arumugam, Y., Glatz, J. \& Tandon, N. 2000. Acute regulation of fatty acid uptake involves the cellular redistribution of fatty acid translocase. J Biol Chem 275, 14501-14508.
Bonen, A., Luiken, J. \& Glatz, J. 2002. Regulation of fatty acid transport and membrane transporters in health and disease. Mol Cell Biochem 239, 181-192.

Bonen, A., Parolin, N., Steinberg, G. et al. 2004. Triacylglycerol accumulation in human obesity and type 2 diabetes is associated with increased rates of skeletal muscle fatty cid transport and increased sarcolemmal FAT/CD36. FASEB J 18, 1144-1146.

Booth, F. \& Lees, S. 2006. Physically active subjects should be the control group. Med Sci Sports Exerc 38, 405-406.

Bruce, C., Anderson, M., Carey, A. et al. 2003. Muscle oxidative capacity is a better predictor of insulin sensitivity than lipid status. J Clin Endocrinol Metab 88, 5444-5451.

Cameron-Smith, D., Burke, L., Angus, D. et al. 2003. A short-term, high-fat diet up-regulates lipid metabolism and gene expression in human skeletal muscle. Am J Clin Nutr 77, 313-318.

Campbell, S., Tandon, N., Woldegiorgis, G., Luiken, J., Glatz, J. \& Bonen, A. 2004. A novel function for fatty acid translocase (FAT)/CD36: involvement in long chain fatty acid transfer into the mitochondria. J Biol Chem 279, 3623536241.

Chabowski, A., Coort, S., Calles-Escandon, J. et al. 2005. The subcellular compartment-tation of fatty acid transporters is regulated differently by insulin and by AICAR. FEBS Lett 579, 2428-2432.

Coe, R., Johnston-Smith, A., Frohnert, B., Watkins, P. \& Bernlohr, D. 1999. The fatty acid transport protein (FATP1) is a very long chain acyl-CoA synthetase. J Biol Chem 274, 36300-36304.

Douen, A., Ramlal, T., Rastogi, S. et al. 1990. Exercise induces recruitment of the insulin-responsive glucose transporter. Evidence for distinct intracellular insulin- and exerciserecruitable transporter pools in skeletal muscle. J Biol Chem 265, 13427-13430.

Ellis, B., Poynten, A., Lowy, A. et al. 2000. Long-chain acylCoA esters as indicators of lipid metabolism and insulin sensitivity in rat and human muscle. Am J Physiol 279, E554-E560.

Febbraio, M., Abumrad, N., Hajjar, D. et al. 1999. A null mutation in murine CD36 reveals an important role in fatty acid and lipoprotein metabolism. J Biol Chem 274, 19055 19062.

Glatz, J., Luiken, J., van Bilsen, M. \& van der Vusse, G. 2002. Cellular lipid binding proteins as facilitators and regulators of lipid metabolism. Mol Cell Biochem 239, 3-7.

Goodpaster, B., Kelley, D., Wing, R., Meier, A. \& Thaete, F. 1999. Effects of weight loss on regional fat distribution and insulin sensitivity in obesity. Diabetes 48, 839-847.

Hamilton, J., Johnson, R., Corkey, B. \& Kamp, F. 2001. Fatty acid transport: the diffusion mechanism in model and biological membranes. J Mol Neurosci 16, 99-108.

Hirsch, D., Stahl, A. \& Lodisch, H. 1998. A family of fatty acid transporters conserved from mycobacterium to man. Proc Natl Acad Sci USA 95, 8625-8629.

Hirshman, M., Goodyear, L., Wardzala, L., Horton, E. \& Horton, E. 1990. Identification of an intracellular pool of glucose transporters from basal and insulin-stimulated rat skeletal muscle. J Biol Chem 26, 987-991. 
Holloway, G., Bezaire, V., Heigenhauser, G. et al. 2006. Mitochondrial long chain fatty acid oxidation, fatty acid translocase/CD36 content and carnitine palmitoyltransferase I activity in human skeletal muscle during aerobic exercise. J Physiol 571, 201-210.

Ibrahimi, A., Bonen, A., Blinn, W. et al. 1999. Muscle-specific over-expression of FAT/CD36 enhances fatty acid oxidation by contracting muscle, reduces plasma triglycerides and fatty acids, and increases plasma glucose and insulin. J Biol Chem 274, 26761-26766.

Itani, S., Ruderman, N., Schmieder, F. \& Boden, G. 2002. Lipid induced insulin resistance in human muscle is associated with changes in diacylglycerol, protein kinase $\mathrm{C}$, and $\mathrm{I} \kappa \mathrm{B}-\alpha$. Diabetes 51, 2005-2011.

Jensen, M. 2002. Fatty acid oxidation in human skeletal muscle. J Clin Invest 110, 1607-1609.

Keizer, H., Schaart, G., Tandon, N., Glatz, J. \& Luiken, J. 2004. Subcellular immuno-localisation of fatty acid translocase (FAT/CD36) in human type-1 and type-2 skeletal muscle fibers. Histochem Cell Biol 121, 101-107.

Kelley, D. \& Mandarino, L. 2000. Fuel selection in human skeletal muscle in insulin resistance. A reexamination. Diabetes 49, 677-683.

Kelley, D., He, J., Menshikova, E. \& Ritov, V. 2002. Dysfunction of mitochondria in human skeletal muscle in type 2 diabetes. Diabetes 51, 2944-2950.

Kennedy, J., Hirshman, M., Gervino, E. et al. 1999. Acute exercise induces GLUT4 translocation in skeletal muscle of normal human subjects and subjects with type 2 diabetes. Diabetes 48, 1192-1197.

Kiens, B. 2006. Skeletal muscle lipid metabolism in exercise and insulin resistance. Physiol Rev 86, 205-243.

Kiens, B., Kristiansen, S., Jensen, P., Richter, E. \& Turcotte, L. 1997. Membrane associated fatty acid binding protein (FABPpm) in human skeletal muscle is increased by endurance training. Biochem Biophys Res Commun 231, 463-465.

Kiens, B., Roepstorff, C., Glatz, J. et al. 2004. Lipid-binding proteins and lipoprotein lipase activity in human skeletal muscle: influence of physical activity and gender. J Apply Physiol 97, 1209-1218.

Koonen, D., Glatz, J., Bonen, A. \& Luiken, J. 2005. Longchain fatty acid uptake and FAT/CD36 translocation in heart and skeletal muscle. Biochim Biophys Acta 1736, 163-180.

Koutsari, C. \& Jensen, M. 2006. Free fatty acid metabolism in human obesity. J Lipid Res 47, 1643-1650.

van Loon, L. \& Goodpaster, B. 2006. Increased intramuscular lipid storage in the insulin-resistant and endurance-trained state. Pflugers Arch 451, 606-616.

van Loon, L., Koopman, R., Manders, R., van der Weegen, W., van Kranenburg, G. \& Keizer, H. 2004. Intramyocellular lipid content in type 2 diabetes patients compared to overweight sedentary men and highly trained endurance athletes. Am J Physiol 287, E558-E565.

Luiken, J., Arumugan, Y., Dyck, D. et al. 2001. Increased rates of fatty acid uptake and plasmalemmal fatty acid transporters in obese Zucker rats. J Biol Chem 276, 4056740573.
Luiken, J., Dyck, D., Han, X. et al. 2002. Insulin induces the translocation of the fatty acid transporter FAT/CD36 to the plasma membrane. Am J Physiol Endocrinol Metab 28, E491-E495.

Luiken, J., Coort, S., Willems, J. et al. 2003. Contractioninduced fatty acid translocase/CD36 translocation in rat cardiac myocytes is mediated through AMP-activated protein kinase signaling. Diabetes 52, 1627-1634.

Pan, D., Lillioja, S., Kriketos, A. et al. 1997. Skeletal muscle triglyceride levels are inversely related to insulin action. Diabetes 46, 983-988.

Perseghin, G., Scifo, P., De Cobelli, F. et al. 1999. Intramyocellular triglyceride content is a determinant of in vivo insulin resistance in humans: a $1 \mathrm{H}-13 \mathrm{C}$ nuclear magnetic resonance spectroscopy assessment in offspring of type 2 diabetic parents. Diabetes 48, 1600-1606.

Pohl, J., Ring, A., Hermann, T. \& Stremmel, W. 2004. Role of FATP in parenchymal cell fatty acid uptake. Biochim Biophys Acta 1686, 1-6.

Report of the Expert Committee 2003. Report of the expert committee on the diagnosis and classification of diabetes mellitus. Diabetes Care 26 (Suppl. 1), S5-S20.

Roden, M., Price, T., Perseghin, G. et al. 1996. Mechanism of free fatty acid-induced insulin resistance in humans. J Clin Invest 97, 2859-2865.

Roepstorff, C., Helge, J., Vistisen, B. \& Kiens, B. 2004. Studies of plasma membrane fatty acid-binding protein and other lipid-binding proteins in human skeletal muscle. Prot Nutr Soc 63, 239-244.

Schaffer, J. \& Lodisch, H. 1994. Expression cloning and characterization of a novel adipocyte long chain fatty acid transport protein. Cell 79, 427-436.

Shulmann, G. 2000. Cellular mechanisms of insulin resistance. J Clin Invest 106, 171-176.

Simoneau, J., Veerkamp, J., Turcotte, L. \& Kelly, D. 1999. Markers of capacity to utilize fatty acids in human skeletal muscle; relation to insulin resistance and obesity and effects of weight loss. FASEB J 13, 2051-2060.

Siri, W. 1956. The gross composition of the body. Adv Biol Med Phys 4, 239-280.

Stahl, A., Evans, J., Pattel, S., Hirsch, D. \& Lodish, H. 2002. Insulin causes fatty acid transport protein translocation and enhanced fatty acid uptake in adipocytes. Dev Cell 2, $477-488$.

Steffensen, C., Roepstorff, C., Madsen, M. \& Kiens, B. 2002. Myocellular triacyl-glycerol breakdown in females but not in males during exercise. Am J Physiol Endocrinol Metab 282, E634-E642.

Stremmel, W., Strohmeyer, G., Brochard, F., Kochwa, S. \& Berk, P. 1985. Isolation and characterization of a fatty acidbinding protein in rat liver plasma membrane. Proc Natl Acad Sci U S A 82, 4-8.

Stump, D., Zhou, S. \& Berk, P. 1993. Comparison of plasma membrane FABP and mitochondrial isoform of aspartate aminotransferase from rat liver. Am J Physiol Gastrointest Liver Physiol 265, G894-G902.

Tunstall, R., Mehan, K., Wadley, G. et al. 2002. Exercise training increases lipid metabolism gene expression in human skeletal muscle. Am J Physiol Endocrinol Metab 283, E66-E72. 
Turcotte, L., Srivastava, A. \& Chiasson, J. 1997. Fasting increases plasma membrane fatty acid-binding protein [FABP $(\mathrm{pm})]$ in red skeletal muscle. Mol Cell Biochem 166, 153-158.

Vistisen, B., Roepstorff, K., Roepstorff, C., Bonen, A., van Deurs, B. \& Kiens, B. 2004. Sarcolemmal FAT/CD36 in human skeletal muscle colocalizes with caveolin-3 and is more abundant in type 1 than in type 2 fibers. J Lipid Res 45 , 603-609.
Wu, Q., Ortegon, A., Tsang, B., Doege, H., Feingold, K. \& Stahl, A. 2006. FATP1 is an insulin-sensitive fatty acid transporter involved in diet-induced obesity. Mol Cell Biol 26, 3455-3467.

Yu, C., Chen, Y., Cline, G. et al. 2002. Mechanism by which fatty acids inhibit insulin activation of insulin receptor substrate-1 (IRS-1)-associated phosphatidyl-inositol 3-kinase activity in muscle. J Biol Chem 277, 3291532922. 